\title{
CERITA RAKYAT DI KECAMATAN 3 NAGARI KABUPATEN PASAMAN
}

\section{Osniwati}

\begin{abstract}
Folktales have motive structure which contains and reflects the people who have it. Its necessary to documenting and archiving the folktales for next generations. This article describes the research result of documentation Kecamatan Tigo Nagari folktales. There are eleven folktales in Tigo Nagari. Nine of them are the people legend and three of them are. Those folktales are 1) Gunung Pasaman dan Talang Perindu, 2) Larangan menanam tebu, serai, kunyit, dan pisang, 3) Bukik Putuih, 4) Inyiak Durian Gunjo, 5) Aia angek di Malayu, 6) Lubuak Gadang, 7) Tajulangek dan Tajugambuang, 8) Larangan Mangulai Paku, 9) Batang Lundang, 10) Rawa Menangis, 11) Datuak dan Harimau.
\end{abstract}

Key word: folktale, documentation, Minangkabau, Tigo Nagari

\section{Pengantar}

Kecamatan Tigo Nagari merupakan salah satu kecamatan yang tanahnya subur dan masyarakatnya hidup dari hasil perkebunan sawit. Selain daerahnya kaya akan penghasilan sawitnya, Tigo Nagari juga menyimpan beragam cerita rakyat yang berkembang di tengah kehidupan masyarakat mereka. Cerita rakyat tersebut banyak dipengaruhi oleh magis. Cerita magis itu oleh masyarakat dijadikan sebagai sebuah kebiasaan atau tradisi dalam kehidupan mereka sehari - hari. Salah satu cerita rakyat yang banyak mempengaruhi pola pikir mereka adalah golongan legenda. Legenda itu hidup subur di tengah - tengah masyarakat Tigo Nagari. Salah satu legenda yang dijadikan sebagai pedoman hidup orang Tigo Nagari adalah legenda tentang suku Piliang. Legenda suku Piliang tersebut sampai saat ini masih terus berpengaruh dalam masyarakat Tigo Nagari, khususnya yang bersuku Piliang dan umumnya dari suku lain.

Hal ini menarik untuk dijadikan bahan kajian. Dalam masyarakat 
Tigo Nagari tidak hanya kehidupan mereka saja yang mengandung unsur magis, akan tetapi sejarah atau cerita dari suatu peristiwa bisa menjadi hal yang mereka keramatkan. Salah satu cerita rakyat yang mereka keramatkan sampai saat ini dan menjadi tradisi adalah legenda suku Piliang. Wujud tradisi yang mereka keramatkan dari legenda ini seperti kuburan. Masih banyak lagi cerita atau legenda yang pada akhirnya berujung kepada pengkeramatan suatu benda.

Tersebutlah Dt. Pusako Alam seorang penghulu suku di Nagari Ladang Panjang yang arif bijaksana, sekaligus seorang ulama yang disegani oleh masyarakat. Selanjutnya seperti kata pepatah, malang tidak dapat ditolak, mujur tidak dapat diraih. Maka pada suatu hari Dt. Pusako alam jatuh sakit. Sakitnya semakin lama semakin parah, dan akhirnya dia meninggal dunia. Kematian Dt. Pusako Alam merupakan duka mendalam bagi masyarakat Ladang Panjang, terutama bagi kaum suku Piliang. Sesuai dengan aturan adat yang berlaku di Tigo Nagari, setelah Dt. Pusako-Alam meninggal maka harus dicarikan gantinya. Maka kaum suku Piliang mengadakan musyawarah pada malam Kamis di rumah kaum suku Piliang untuk mencari gantinya. Malam Kamis bagi masyarakat Tigo Nagari adalah malam yang diistimewakan karena malam ini diadakan acara wirid atau pertemuan mingguan di mesjid Dt. Pusako Alam. Hasil dari musyawarah tersebut didapatkan kesepakatan sebagai ganti Dt. Pusako Alam adalah Munawir. Munawir adalah kemenakan satu - satunya dari Dt. pusako Alam. Malam itu juga diputuskanlah bahwa Munawir yang akan menggantikan Dt. Pusako Alam.

Seminggu setelah kesepakatan itu diadakan acara pengangkatan datuak baru yaitu Munawir Dt. Pusako Alam yang dilaksanakan pada hari Kamis sampai malam hari. Pada malam itu semua orang berkumpul di rumah kaum suku Piliang untuk mengadakan selamatan atas pengangkatan Dt. Pusako Alam yang baru. Umumnya acara adat di Kecamatan Tigo Nagari diadakan pada malam sampai pagi. Tepat jam 12 malam ketika semua niniak mamak mengadakan dialog atau maota - ota terdengar suara inyiak (harimau) yang tidak jauh dari rumah tempat musyawarah. Ketika itu melihat Munawir ke luar rumah di pekarangan dilihat lah inyiak kecil (anak harimau).

Semenjak kejadian itu, gemparlah kaum suku Piliang bahwa almarhum Dt .Pusako Alam menjelma menjadi inyiak jadi-jadian. Hal itu dibenarkan pula oleh Munawir bahwa mamaknya telah menjadi inyiak, hal itu dibuktikan pula dengan kuburan Dt. Pusako Alam yang berlubang. 
Kuburan itu kemudian dipercayai oleh masyarakat sebagai kuburan keramat. Sampai saat ini kuburan Dt.Pusako Alam masih dikunjungi oleh orang-orang untuk berziarah. Ziarah kubur diadakan pada bulan bulan tertentu seperti bulan Zulhijah, dan saat itu diberlakukan pula larangan memasak gulai paku (sejenis pakis) karena diyakini bahwa saat bersamaan akan terjadi perkelahian antara harimau suku Piliang dan harimau dari daerah Kerinci.

Semenjak itu jika ada Datuak dari suku Piliang yang meninggal dunia maka kuburannya akan berlubang dan di depan rumahnya harus dipasang kain ganiah (putih). Hal itu untuk menghormati dan memberi kekuatan pada calon inyiak baru. Selain itu keunikannya terletak pada pemasangan kain ganiah di loteng selama satu masa yang dihitung duo kali tujuah atau dua kali tujuh (diceritakan oleh Nuan Dt.Bandaro Basa yang berusia 70 tahun seorang penghulu suku Piliang).

Unsur - unsur yang terkandung dari cerita rakyat yang ada di Kecamatan Tigo Nagari di atas antara lain adanya tokoh binatang yang paling ditakuti yaitu harimau. Adanya pemimpin tertinggi dalam mengambil keputusan dalam kaum yaitu datuak, dan kebanggaan dari etnis tertentu. Misalnya masyarakat yang percaya bahwa inyiak adalah binatang yang paling besar dan bisa menjaga martabat dan keselamatan di mata masyarakat lain. Unsur - unsur itu akan peneliti polakan dan gambarkan sebagai struktur cerita rakyat yang ada di Kecamatan Tigo Nagari.

Cerita rakyat tersebut menarik untuk diteliti, karena terdapat kekuatan yang mempengaruhi pola pikir masyarakatnya. Hal itu berpengaruh pula kepada cara hidup dan pandang mereka pada suatu objek.

Selain cerita di atas, masih banyak lagi cerita rakyat lainnya yang berkembang di tengah-tengah masyarakat. Akan tetapi, banyak generasi penerus yang tidak mengetahui cerita rakyat tersebut dan orang yang mengetahui cerita rakyat ini pun saat sekarang sudah berkurang karena kebanyakan orang-orang yang mengetahui cerita ini hanyalah orang tua saja.

Oleh karena itu, penelitian terkait dengan keberadaan cerita rakyat di Kecamatan Tigo Nagari menjadi penting untuk dilakukan. Asumsi ini didasarkan pada pentingnya usaha pendokumentasian dan melihat struktur setiap cerita rakyat, sehingga dapat dilihat motif yang melingkupi cerita rakyat tersebut. Lebih lanjut, upaya pendokumentasian ini diharapkan menjadi langkah awal untuk kemudian dilanjutkan dengan melakukan 
analisis struktural berdasarkan motif dari setiap cerita rakyat yang ada di kecamatan Tigo Nagari tersebut.

\section{Landasan teori}

Di dalam ilmu folklor unsur-unsur sebuah cerita atau bagian cerita yang dapat dipergunakan sebagai satuan analisis disebut motif. Di dalam dongeng unsur-unsur ini dapat berupa: gajala alam, binatang, suatu konsep, suatu perbuatan, penipuan terhadap suatu tokoh dan lain- lain.

Struktur naratif menurut Hoed memiliki beberapa ciri, antara lain : pertama Imanensi, yakni analisis struktural yang melihat struktur dalam rangka sistem dan dalam persfektif sinkronis. Jadi, struktur adalah suatu bangun yang abstrak yang komponen-komponennya terikat dalam suatu jaringan relasi, baik di dalam struktur maupun di luar struktur (secara asosiatif). Kedua Partinensi, yakni analisis makna suatu komponen struktur dengan mengindentifikasi ciri pembeda di antara komponen tersebut dengan komponen - komponen yang lain dalam rangka suatu sistem. Akhirnya, ciri pembeda itu sendiri menjadi lebih dipentingkan dari pada komponennya sendiri.

Ketiga Komutasi, yakni analisis struktural menggunakan tes komutasi, yakni tes oposisi pasangan minimal untuk mengidentifikasi ciri pembeda antara satu komponen struktur dengan komponen yang lain dalam suatu sistem. Keempat Kompatibilitas, yakni analisis struktural melihat komponen-komponen struktur dalam rangka kombinasi dan kesesuaian antar komponen. Kelima Integrasi, analisis struktural melihat struktur sebagai suatu kesatuan (totalitas) dalam suatu sistem.

Keenam Sinkroni, yakni sebagai dasar analisis diakronis. Analisis diakronis adalah analisis berdasarkan poros waktu (memperlihatkan pekembangan), sedangkan analisis singkronis adalah analisis pada satu lapisan waktu dan ruang dalam poros waktu. Dalam melakukan kajian diakronis, analisis struktural bertumpu pada lapisanlapisan analisis sinkronis. Ketujuh Fungsi, yakni analisis struktural melihat komponenkomponen struktur dalam suatu sistem sebagai fungsi tertentu atau dalam hal bahasa, fungsi dilihat dalam rangka komunikasi (Danandjaja 2009:113) .

Struktur naratif lain yang bisa digunakan dalam kajian sastra lisan adalah cara Dundes. Menurut Dundes, sastra lisan terutama cerita (dongeng ) memiliki struktur yang saling terkait satu sama lain. Dalam sastra lisan unsur cerita yang paling utama adalah motif. Motif dapat berupa gejala 
alam, binatang, penipuan, dan lain - lain.

Cerita rakyat dapat dipotong menjadi beberapa bagian. Setiap bagian disebut motifen. Motifen ini akan membentuk struktur yang teratur. Tentu saja teori ini lebih banyak digunakan untuk menarik benang merah ceritacerita di suatu wilayah. Garis itu disebut dengan kecendrungan motif.

Menurut Alan Dundes, kajian struktur naratif motif di pusatkan pada masalah makna dan fungsi. Dengan cara ini maka diperoleh pemahaman tentang: (a) tipologi cerita rakyat, (b) asal-usul cerita rakyat, (c) sejauh mana perubahan terjadi, akulturasi, dan metamorfosis. Kajian semacam ini di samping memiliki makna historis difusionisjuga untuk menjelaskan struktur spesifik sebuah cerita. Spesifikasi dongeng misalnya saja menghadirkan hukum (1) sebuah dongeng akan mengungkapkan struktur pembuka cerita melalui pelukisan dunia harmonis, (2) akan dibuka dengan" nuju sawijining dina" (pada suatu hari), (3) hadirnya musuh atau tantangan, (4) ada "liding" dongeng, (5) ada pengulangan, (6) tokoh baik selalu menang, (7) tokoh baik selalu cerdas, dan tokoh jelek hanya mempergunakan kekuatan tubuhnya, dan sebagainya ( Endraswara, 2009:116 ).

Struktur folklor yang berupa cerita (tale), menurut Dorson perlu diungkap masalah: (a) types and motifs, yakni setiap cerita pasti ada tipologi dan motif yang diangkat, seperti halnya kejujuran, keadilan, dan lain - lain, (b) framework, yakni bagaimana formula yang diterapkan narator. Bagaimana narator menghubungkan dengan situasi. Mungkin pola menyedihkan, humor, memberi petuah dan lain - lain, (c) figure of speech, yakni adalah keindahan cerita yang terkait dengan nilai - nilai tertentu, seperti kebijaksanaan, horor, dan seterusnya, (d) formulaic verbal sequences, yakni seperti halnya monolog, komentar narator, stereotif dialog, (e) repedition of certain passage, sequences, artinya terkait dengan bagaimana pencipta menyambung cerita, mengakhiri, menanjakkan, dan seterusnya apakah ada keberulangan atau tidak (Endraswara,2009:116)

Dalam kaitannya dengan cerita rakyat, ada tiga kategori cerita yang dikemukakan juga oleh Dorson. Pertama magis tale, artinya cerita yang berkaitan dengan hal-hal magic. Tipe ini biasanya berkaitan dengan kisah supranatural. Kedua religious tale, artinya kisah yang terkait dengan masalah keyakinan. Ketiga romantic tale, artinya kisah yang memuat percintaan (Endraswara 2009: 117).

Levi-Strauss menyatakan bahwa dalam pandangan struktural, akan mampu melihat fenomena sosial budaya yang mengekspresikan seni, ritual, 
dan pola-pola kehidupan. Selanjutnya Levi-Strauss menjelaskan bahwa dalam mitos terdapat hubungan unit-unit (yang merupakan struktur) yang tidak terisolasi, tetapi merupakan kesatuan relasi-relasi hubungan tersebut dapat dikombinasikan dan digunakan untuk mengungkap makna dibalik mitos itu (Endraswara, 2009:120).

Levi-Strauss juga menyatakan bahwa penciptaan mitos memang tidak teratur sebab si empunya cerita, biasanya menceritakan kembali ceritanya sekehendak hati. Namun, di balik ketidakteraturan itu mitos tersebut sebenarnya ada keteraturan yang tidak disadari oleh penciptanya. Keteraturan-keteraturan itu sering disebut struktur (Endraswara, 2009:120).

Dalam penelitian ini, peneliti akan menggunakan teori struktural naratif. Peneliti akan mencoba melihat bagaimana motif dan fungsi dalam cerita sehingga akan ditemukan pola cerita dan kaitan cerita satu dengan cerita yang lainnya.

\section{Metode dan teknik}

Metode adalah prosedur kerja yang ditempuh sedangkan teknik adalah cara yang spesifik dalam memecahkan masalah (Suriasumantri,1996:330). Penelitian ini menggunakan metode kualitatif. Metode terhadap objek ini menitik beratkan pada pemahaman atau penafsiran. Maksudnya, penelitian tidak hanya menfokuskan pada folklor saja namun lore nya juga. Kedua unsur ini sangat erat kaitannya. Data utama dari penelitian ini adalah katakata dan tindakan dari informan itu sendiri, yang merupakan masyarakat Kecamatan Tigo Nagari. Penelitian ini juga menggunakan data tambahan, seperti foto, buku, serta hasil penelitian yang berkaitan dengan penelitian ini.

Penelitian ini adalah penelitian lapangan. Untuk mendapatkan data dilakukan dengan teknik rekam, yakni merekam cerita dari tuturan narasumber. Selanjutnya peneliti menganalisis dengan struktural. Dengan demikian tahapan penelitian yang akan penulis lakukan adalah sebagai berikut.

Peneliti melakukan upaya pengamatan dan pengenalan secara lebih dekat terhadap masyarakat di Kecamatan Tigo Nagari, baik sebagai peneliti yang terjun langsung kelapangan, maupun sebagai peneliti yang tidak langsung terjun kelapangan. Langkah ini penting, karena usaha ini akan dapat menjalin hubungan yang harmonis antara peneliti dengan masyarakat di Kecamatan Tigo Nagari, sehingga dalam melakukan 
tahapan penelitian lebih lanjut, peneliti tidak merasa asing, sekaligus tidak menemukan kendala yang berarti.

Wawancara yang dilakukan adalah wawancara tertutup. Wawancara tertutup yaitu wawancara yang dilakukan terhadap informan pilihan yang dianggap layak. Informan yang akan penulis waawancarai adalah; a. Pemuka masyarakat yang terdiri dari ninik mamak, alim ulama, cerdik pandai, dan tokoh masyarakat lainnya; b. Informan tinggal menetap minimal lima belas tahun secara berturut-turut di nagari tersebut, dan c. Informan warga asli, bukan pendatang.

Selanjutnya peneliti mengklasifikasikan cerita rakyat yang diperoleh ke dalam jenis-jenis folklor yang berlaku secara umum, dan dilakukan analisis sesuai dengan tujuan penelitian.

\section{Pembahasan}

Secara keseluruhan penelitian ini mengacu kepada kaidah dasar folklor. Prosedur kerja yang ditempuh dengan menggunakan berbagai cara untuk mendapatkan hasil akhir (Suriasumantri, 1985:37). Dengan menggunakan metode penelitian kualitatif data utama penelitian ini adalah cerita. Sebagaimana di ungkapkan Danandjaja (Endraswara, 2003:62), penggunaan metode kualitatif dalam penelitian folklore umunya serta penelitian terhadap cerita rakyat yang ada di kecamatan Tigo Nagari disebabkan oleh kenyataan setiap cerita rakyat tersebut mengandung unsur- unsur budaya yang diamanatkan masyarakat kecamatan Tigo Nagari sebagai pemilik dan pemelihara cerita rakyat tersebut. Artinya, peneliti tidak hanya menitikberatkan upaya penelaah pada unsur folk dari setiap cerita rakyat tersebut, namun juga unsur lore-nya . Kedua unsur ini saling terkait sekaligus membentuk sebuah komunitas kebiasaan ritual atau benda keramat masyarakat kecamatan Tigo Nagari yang unik.

Data utama dalam penelitian kualitatif adalah kata - kata dan tindakan. Selebihnya adalah data tambahan seperti dokumen dan lainlain. Selanjutnya pada penelitian kualitatif data bersumber dari manusia (human sources) berupa data dan tindakan, sekaligus data diluar manusia (non human sources) berupa buku, dokumen dan foto ( Endraswara, 2003: 207-208).

Oleh sebab itu, berhubungan dengan metode dan teknik pendokumentasian cerita rakyat yang ada di kecamatan Tigo Nagari dilakukan beberapa tahapan, yaitu: 1) studi pustaka ;2) observasi lapangan 
; dan analisis data. Terkait dengan cerita rakyat dan strukturnya maka penting dilakukan studi pustaka guna mendapat segala informasi yang terkait dengan objek.

Menurut Brunvad (Danandjaja, 1991:67) ada empat klaasifikasi cerita rakyat yang tergolong kepada legenda, yaitu : legenda keagamaan (religious legends), legenda alam gaib (supernatural legends), legenda perseorangan (personal legends), dan legenda setempat ( local legends). Cerita rakyat yang terdapat di kecamatan Tigo Nagari jika ditinjau berdasarkan pengklasifikasian yang dikemukakan oleh Jan Harol Brunvad termasuk ke dalam jenis legenda.

Untuk cerita rakyat berjenis dongeng telah dikemukakan oleh Anti Aarne dan Stith Thomson (Danandjaja, 1984:86) mengatakan bahwa dongeng dapat dikelompokan menjadi empat kelompok besar, yaitu dongeng binatang (animal tales), dongeng biasa (ordinary folkatales), lelucon dan anekdot (jokes and anecdotes), dan yang terakhir adalah dongeng berumus (formula tales). dongeng binatang (animal tales), yaitu dongeng yang ditokohi oleh binatang-binatang peliharaan dan juga binatang liar, seperti binatang menyusui, burung, binatang melata (reptilia), ikan dan serangga. Binatang-binatang dalam dongeng ini diyakini dapat berbicara dan berakal budi seperti layaknya manusia.

Dongeng biasa (ordinary folktales), yaitu dongeng yang ditokohi oleh manusia dan biasanya adalah kisah suka duka seseorang. Lelucon dan anekdot (jokes and anecdotes), yaitu dongeng-dongeng yang dapat menimbulkan rasa mengelikan hati, sehingga dapat menimbulkan ketawa bagi yang mendengarnya, Namun bagi suatu kelompok tertentu dongeng tersebut dapat juga menimbulkan rasa sakit hati. Terakhir adalah dongeng berumus (formula tales), yaitu disebabkan strukturnya yang mengalami pengulangan. Oleh sebab itu, sesuai dengan pengklasifikasian yang telah dikemukan sebelumnya, maka cerita rakyat yang terdapat di Kecamatan Tigo Nagari dapat dikelompokan kepada jenis legenda. Berdasarkan jenis legenda, maka cerita rakyat di Kecamatan Tigo Nagari ini dapat dikelompokan menjadi beberapa jenis legenda, seperti yang terlihat pada tabel di bawah ini :

Klasifikasi Cerita Rakyat di kecamatan Tigo Nagari

\begin{tabular}{|c|l|l|}
\hline No & \multicolumn{1}{|c|}{ Cerita Rakyat } & Klasifikasi Cerita \\
\hline 1. & Gunuang Pasaman dan talang perindu & Legenda Setempat \\
\hline
\end{tabular}


Cerita Rakyat di Kecamatan 3 ...

\begin{tabular}{|c|l|l|}
\hline 2. & $\begin{array}{l}\text { Larangan menanam tebu, serai, kunyit dan } \\
\text { pisang }\end{array}$ & Legenda Setempat \\
\hline 3. & Bukik putuih & Legenda Setempat \\
\hline 4. & Inyiak durian gunjo & Legenda Setempat \\
\hline 5. & Aia angek di malayu & Legenda Setempat \\
\hline 6. & Lubuak adang & Legenda Setempat \\
\hline 7. & Tajulangek dan tajugambuang & Dongeng biasa \\
\hline 8. & Larangan mangulai paku & Legenda Alam gaib \\
\hline 9. & Batang Lundang & Legenda Setempat \\
\hline 10. & Rawa menangis & Legenda Setempat \\
\hline 11. & Datuak dan Inyiak & Legenda Alam gaib \\
\hline
\end{tabular}

Oleh karena keterbatasan ruang, artikel ini tidak menampilkan semua cerita rakyat yang diperoleh. Bberapa di antaranya adalah sebagai berikut.

\section{a. GUNUANG PASAMAN dan TALANG PERINDU}

Konon kabarnya pada zaman dahulu, di gunuang pasaman banyak menyimpan keangkeran. Menurut informan salah satu keajaiban yang terdapat di gunung pasaman, ada helikopter orang belanda yang lewat di puncak gunung tersebut dan tiba-tiba langsung jatuh ketika tepat berada di puncaknya. Ketika dilihat oleh warga helikopter tersebut langsung raib. Setelah diselidiki oleh masyarakat setempat memang tidak ditemukan adanya helicopter jatuh. Selain itu ada keajaiban yang tersimpan di sekitar puncak gunung pasaman. Menurut pengalaman dan pengamatan informan ada satu telaga (sejenis kolam) yang terdapat di tengah - tengah gunung dan bisa dijumpai dengan berjalan kaki sekitar 8 jam.Telaga itu sangat besar dan airnya jernih. Konon kabarnya telaga tersebut dijaga oleh seekor ular naga dan sebangsa kalajengking. Kemudian lebah penghasil madu juga ikut memberikan kesan angker kepada telaga ini.

Pernah suatu ketika kabar beredar di masyarakat. Ada serumpun talang perindu yang berada di telaga.Talang adalah sejenis bambu, talang perindu inilah pada zaman dahulu sering memancing orang untuk datang kegunung Pasaman. Talang perindu merupakan sebuah benda yang ajaib, keajaiban nya terletak kepada siapa saja yang mendapatkan talang perindu ini hidupnya akan sukses dan kaya raya. Akan tetapi tidak untuk mengambil talang perindu perlu pengorbanan yang tidak sedikit, adakalanya berkorban nyawa. Untuk itulah sampai sekarang belum ada orang yang berhasil mendapatkannya walaupun talang perindu diyakini 
keberadaanya oleh masyarakat.

Selain itu gunung Pasaman merupakan kebanggaan bagi masyarakat malampah. Dengan adanya gunung ini masyarakat bisa hidup makmur dan sejahtera, karena di gunung pasaman ini masyarakat bisa mengolah tanah untuk ditanami berbagai tanaman, seperti sawit, cabe, coklat, jati dan sebagainya. Kesemuanya itu merupakan sumber mata pencaharian bagi masyarakat, dan masyarakat tidak takut lagi terjadi gagal panen atau kemalingan karena masyarakat percaya perkebunan mereka sudah ada yang menjaganyanya yaitu penjaga telaga dan buluh perindu.

Sampai sekarang masyarakat sangat takut untuk menaiki puncak gunung pasaman itu, kalaupun ada masyarakat yang berladang tapi tidak akan berani sampai kepuncaknya seperti gunung merapi. Gunung pasaman terletak di kenagarian Malapah, Jorong kampuang tabek. Gunung Pasaman ini bisa dilihat dari pasaman barat, tepatnya di simpang empat akan terlihat terpisah dengan gunung talamau, padahal gunung itu sangat berdekatan ibarat gunung kembar akan tetapi ada perbedaan kedua gunung tersebut kalau gunung pasaman lebih tinggi dari gunung talamau. Selain itu gunung pasaman menyimpan misteri yang dijaga oleh masyarakatnya.

Demikianlah cerita Gunung pasaman yang peneliti dapatkan dari seorang penghulu suku Jambak.Cerita tentang gunung pasaman ini diketahui oleh semua masyarakat nagari Malampah. Gunung pasaman dan talang perindu ini peneliti golongkan ke dalam jenis legenda yaitu legenda setempat.

\section{b. LARANGAN MENANAM TEBU, SERAI, KUNYIT, PISANG}

Ada sebuah kampung yang di huni oleh sekelompok kaum yang saparuik. kaum ini mempunyai tanah yang disediakan khusus untuk menanam tanaman hijau, seperti kunyit pisang dan lain sebagainya. Entah apa yang terjdi tiba- tiba datang penyakit aneh menyerah salah satu keluarga kaum. Menurut pendapat sebagian masyarakat, Hal ini disebabkan oleh adaik salingka nagari bahwa air daun pisang tersebut jatuh pada tabu dan serai. Itulah dikatakan talampau pantang atau pantangan setempat dan bisa mengakibatkan nyawa kaum bisa melayang.

Alkisah, Pada suatu hari salah satu anak kaum tersebut sakit keras. Sakitnya tidak ada sembuh- sembuh padahal sudah banyak didatangkan datu, untuk mengobati anak tersebut. Datu merupakan orang yang sudah dipercaya dapat mengobati berbagai macam penyakit, akan tetapi tidak 
satunpun dari Datu tersebut bisa mengobati penyakit anak itu. Bahkan Datu yang paling pintarpun angkat tangan dengan penyakit anak ini. Ada seorang Datu yang bisa menanuang, tanuang adalah sejenis ramalan yang digunakan untuk melihat penyakit yang diderita oleh si sakit

Datu itu menemukan semacam pantangan di sini disebut basuo pantang. Basuo pantang ini sanagat berat dan susah diobati kecuali melakukan mambayia pantang. Mambayia pantang ini sejenis tumbal tetapi yang digunakan adalah ayam, atau kambing. Dalam basuo pantang ini ditemukan bahwa kaum tersebut, lebih tepatnya orang tua tersebut menanam tebu, serai, kunyit dan pisang dalam satu kebun. Datu itu mengatakan dalam tenungannya ia melihat air daun pisang itu mengalir ke rumpun kunyit, tebu dan serai, itu bisa membuat orang yang punya kebun itu sakit, dan bahkan bisa meninggal. Kalau tidak cepat mambayia pantang maka tujuh orang dalam kaun tersebut akan meniggal dunia dalan waktu tujuh hari berturut - turut.

Setelah dibayia pantang dengan menyembelih ayam dan memasangkan sejenis kain putih yang sudah ditulisi ayat- ayat Al-gur'an di pangkal lengan anak tersebut sering disebut simaik. Simaik ini sampai sekarang masih sering ditemukan dalam pengobatan tradisional di kecamatan Tigo Nagar. Beberapa hari kemudian, anak itu mulai sadar. Kata Datu tersebut tidak cukup mambayia pantang saja, kaum itu harus memusnahkan kunyit, tebu, serai dan pisang tersebut dengan di bakar. Semenjak saat itu sampai sekarang tidak kita temukan mereka menanam kunyit, pisang ,tebu dan serai dalam satu tempat.

Cerita ini informan dapat dari nenek sewaktu masih kecil, cerita ini merupakan kepercayaan bagi mayarakat karena sampai saat ini tidak ada kita temui masyarakat tersebut menanam tebu, serai, pisang dan kunyit dalam satu kebun. Hal ini terjadi karena masyarakat menganggab pantangan mengenai empat jenis tanaman masih berlaku sampai sekarang.

\section{c. LUBUAK GADANG}

Lubuak gadang berada di nagari Binjai. Beberapa tahun yang lalu di Binjai ada salah satu sungai yang tidak besar, akan tetapi disungai inilah nantinya kita akan melihat ikan yang besar sementara airnya tidak banyak dan sungainya dangkal.

Alkisah ada seorang yang punya mantra untuk mambuat lauak larangan. Dalam mantra ini tidak boleh ada orang lain nantinya yang ikut 
membuka lauak larangan setelah besar. Syarat yang diminta oleh datuak tersebut antara lain,pertama kain putiah sebagai tanda untuk manusia dan bangsa jin bahwa kawasan itu tidak boleh mencari ikan. Kakek itu juga memberikan gambaran bahwa tidak bangsa manusai saja yang mencari ikan tapi bangsa jin juga. Syarat yang kedua kemenyan, kemenyan ini berguna untuk menandakan bahwa setelah kemenyan itu dibakar maka kawasan yang ditancapakan kain putih baik yang di hulu maupun yang dihilir tidak boleh menangkap ikan lagi.

Semenjak saat itu sudah ditetapkan oleh masyarakat, bahwa lubuak tersebut sudah diuduah. Istilah uduah digunakan oleh masyarakat Binjai untuk mengatakan bahwa sesuatu baik berupa apapun(kebun, padi, ladang) sudah dimantrai oleh orang yang sakti, dan tidak boleh diganggu lagi. Kalau sudah ada tanda kain puntih itu berarti ikan disungai tersebut tidak boleh diambil lagi. Kalau ternyata ada warga masyarakat yang melakukan tindakan yang membahayakan misalnya dengan mencuri ikan, maka ia akan mati. walaupun yang ikut makan ikan tersebut seluruh keluarga akan tetapi hanya yang bersangkutan saja yang mati, begitu akibat dari uduah tersebut.

Karena beratnya berjanjian dengan penguasa ikan, air dan manusia makan ikan tersebut akan cepat besar.hal ini dipercaya masyarakat bahwa ikan tersebut setelah dibacai mantra bias besar dalam hitungan minggu tanpa makanan dalam artian dikasih makan,karena ikan tersebut akan dating dengan sendirinya tanpa disemai benih ikan,sebab menurut kakek itu ikan tersebut dating mencari perlindungan.

Semenjak itu,tidak ada yang berani lagi mengambil ikan disana.kakek yang mauduah ikan tersebut sekarang sudah meninggal, akan tetapi tidak ada yang berani mengambil ikan tersebut.padahal ikan tersebut sangat banyak dan sudah besar-besar.,menurut informan, cucu dari kakek tersebut ,sampai saat ini tidak ada keinginan dari masyarakat untuk membuka larangan ikan tersebut, ikan tersebut sekarang dijadikan objek wisata di nagari Binjai.Menurut dia juga, ikan yang ada di lubuak gadang itu ada yang sebesar kuda, dia akan keluar pada saat sholat idul adha dan sholat idul fitri.

\section{d. BATANG LUNDANG}

Batang lundang adalah nama sebuah sungai yang mengalir dari kaki gunugna pasaman.batang lundang ini tidak terlalau besar,kalau 
dilihat malah lebih besar sedikit dari Bandar.akan teteapi ,banyak membuat masyarakat mengalami keajadian aneh dari batang lundang dan sampai sekarang batang lundang masih dipercaya oleh masyarakat ada penghuninya yaitu sejenis.

Pada suatu waktu ada seorang nenek yang datang dari luar kecamatan tigo nagari, nenek inilah yang nantinya mengalami kejadian diluar nalar dan logika manusia.sebenarnya kalau seorng nenek tidak bias bekerja mencari uangtapi nenek ini agak lain dia bias mencari nafkah sendri tanpa mengharapkan dari familinya sebab dia tidak punya family dekat lagi untuk itu dia berusaha mencari penghidupan sehingga mambawa dia dating ke kecamatan tigo nagari dan tinggal bersama sebuah keluarga di aia lundng.

Suatu ketika nenek ini selesai bekerja disawah salah sorang warga , tanpa berkpikir panjang dia langsung mandi ke batang lundang.kira - kira jam 12.30.selang beberapa hari kemudian nenek ini sakit keras dn tidak bisa makan dan minum selama tiga bulan.nenek itu sering minta antar ke batang lundang itu selama sakitnya.

Semenjak nenek tersebut sakit, banyak orang yang merasa kehilangan, sebab nenek itu sering menolong para petani.setelah sakitnya tidak bisa diobati lagi, nenekt tersebut meniggal dunia.mayatnya dimakamkan di pemekaman umun di dekat air lundang.air lundang adalah nama sebuah kampong yang berada di nagari ladang panjang. Setelah nenek tersebut meniggal banyak kejadian aneh yang terjadi di air lundang.salah satu yang dialami oleh warga, suatu ketika ada warga yang mandi di batang lundang pada sore hari, dan pada malam harinya di bermimpi dibawa oleh sekelompok orang oergi ke suatu tempat yang indah dan banyak ularnnya. setelah terbangun dari mimpinya badan nya biru dan lebam seperti habis terjatuh.

Kejadian seperti itu terus terjadi beberapa kali setiap ada yang mandi di Batang lundang, sehingga masyarakat memandang bahwa batang lundang ada penghuninya. Pernah pula suatu kejadian, ada rumah masyarakat dekat dengan Batang lundang itu dan tiba-tiba pada suatu malam ada seekor ular yang sebesar batang kelapa jatuh dari loteng. Semenjak kejadian itu bertambah kencar orang membicarakan keangkeran Batang lundang tersebut, sehingga jarang sekali orang yang mau lewat ataupun mandi di Batang lundang tersebut.

Cerita ini disampaikan didapat oleh informan dari neneknya. Dari semenjak zaman neneknya dahulu hingga sekarang orang masih 
beranggapan bahwa ular yang paling besar berada di Batang lundang. Kalau kita lewat di Batang lundang itu memang tidak ada kesan angker, akan tetapi ada aura tersendiri peneliti rasakan ketika melewatinya.

\section{e. RAWA MENANGIS}

Bancah sibarunguik "rawa menangis " adalah sebuah kawasan rawa - rawa di Binjai Kecamatan Tigo nagari Kabupaten Pasaman. Dikatakan

" bancah sibarunguik" karena di kawasan rawa - rawa tersebut sering terdengar suara tangisan dan penduduk disana percaya bahwa kawasan tersebut tempat terkubur nya seorang bangsawan sakti dari kerajaan Bontang yang berada di Pasaman pada zaman dahulu.

Cerita bancah sibarunguik ini erat kaitannya dengan cerita "berdiri sebuah rumah gadang semalam". Dari informasi yang didapat dari seorang informan yang dapat dipercaya menceritakan bahwa pada masa dahulu ada seorang bangsawan dari kerajaan Bontang yang mempunyai watak ambisius dan keras kepala, ia mempunyai kekuatan supranatural.

Ia diasingkan oleh pihak kerajaan karena mempunyai watak yang keras, tidak mau peduli dengan orang lain bahkan kepada ibunya sendiri ia durhaka. Setelah ia diasingkan oleh pihak kerajaan ia bersumpah kepada ibunya akan membangun sebuah kerajaan sendiri. Enjengar sumpah yang diikrarkannya ibunya merasa sedih dan memperingatkan agar niatnya diurungkan saja. Tetapi dengan kekuatan yang dimilikinya ia membangun sebuah kerajaan "rumah gadang" dengan bantuan bala tentara makluk ghaib yang dimilikinya. Ia bersumpah " jika tidak bisa mendirikan sebuah kerajaan dalam waktu satu malam maka ia akan termakan oleh tanah (bumi). Karena sifat kesombongan dan takabur, ia malah termakan oleh janjinya sendiri.

Karena waktu keburu pagi dan penyelesaian pembuatan kerajaan "rumah gadang" belum juga terselesaikan, maka ia meminta maaf kepada ibunya namun, apa dikata ia telah bersumpah "jika tidak bisa mendirikan sebuah kerajaan dalam waktu satu malam maka ia akan termakan oleh tanah (bumi). Seketika itu juga kerajaan "rumah gadang" yang belum selesaikan hilang begitu saja dan bangsawan itu merasa malu kepada ibu dan dirinya sendiri. Tanpa pikir panjang ia menaiki kuda dan lari ke arah perbukitan. Namun, malang baginya kaki kuda yang ditungganginya masuk ke dalam lubang di daerah rawa - rawa yang cukup dalam. Ia terjatuh dan masuk ke dalam rawa tersebut, malang baginya ia tidak bisa keluar dari rawa - rawa 
tersebut. Ibunya berusaha untuk menyelamatkannya namum takdir berkata lain, ia tenggelam dalam rawa - rawa yang seakan menghisap dirinya ke dalam bersama kuda yang ia naiki.

Pada saat sekarang ini, di kawasan rawa tersebut muncul sebuah mata air yang dipercaya oleh masyarakat sekitar bisa menyembuhkan segala macam penyakit dan barang siapa yang melakukan sebuah ritual atau bersemedi dekat mata air tersebut percaya akan mendapatkan kesaktian pula. Namun, pada saat sekarang masyarakat sekitar merasa takut apabila melewati kawasan tersebut disaat malam menjelang, karena sering terdengar tangisan orang yang minta maaf dan minta tolong.

\section{Penutup}

Kecamatan Tigo Nagari terletak di kabupaten Pasaman sumatera barat. Kecamatan Tigo Nagari sesuai dengan namanya mempunyai tiga buah nagari, yaitu nagari Malampah, nagari Ladang Panjang, dan nagari Binjai. Setiap komunitas masyarakat selalu memiliki cara khas untuk merepresentasikan pandangan hidup mereka melalui sebuah media. Masyarakat Tigo Nagari memiliki cerita rakyat yang diyakini benar adanya.

Dokumentasi adalah satu langkah kecil dalam pemeliharaan dan pelestarian hasil-hasil tradisi lisan. Muatan kearifan local yang terkandung dalam tradisi lisan pada akhirnya dapat digunakan untuk mengembangkan daerah yang bersangkutan.

\section{Daftar Pustaka}

Arifin, Max. 1981. Cerita Rakyat Nusa Tenggara Timur. Jakarta: Departemen Pendidikan dan Kebudayaan.

Danandjaya, James. 1984. Folklor Indonesia: Ilmu Gosip, Dongeng dan Lainlain Jakarta: Pustaka Utama Grafiti

Endaswara, Suwardi. 2009. Metedologi Penelitan Folklor Yokyakarta: Media Pressindo.

Fauza, Rahmatul. 2008. "Asal -usul Nama Nagari di Kecamatan Baso" (Skripsi SI Fakultas Sastra UNAND). Padang: Fakultas Sastra Universitas Andalas.

Gani, Hadi. 1981. Cerita Rakyat Sulawesi Tengah. Jakarta: Departemen Pendidikan dan Kebudayaan.

Koentjaraningrat. 1983. Metode Penelitian Masyarakat. Jakarta: Gramedia. Marleni, Rosna. 2008. "Dokumentasi dan Klasifikasi Cerita Rakyat di Kenagarian Sungai Naniang" (Skrisi SI Fakultas Sastra UNAND). Padang: Fakultas Sastra Universitas Andalas.

Navis, Anas. 2004. Cerita Animisme di Minangkabau. Padang: Pusat Pengkajian 
Islam dan Minangkabau (PPMI) Minangkabau.

Purwanto, Andi. 2010. "Analisis Isi dan Fungsi Cerita Prosa Rakyat di Kanagarian Koto Besar Kabupaten Damasraya". (Skripsi SI Fakultas Sastra UNAND). Padang: Fakultas Sastra Universitas Andalas.

Salmadanis, dkk. 2003. Adat Basandi Syarak, Nilai dan Aplikasi Mennuju Kembali Nagari dan Surau, Jakarta : PT Kartika Insan Lestari Pres.

Suriasumantri, Jujun. 1996. Filsafat Ilmu Sebuah Pengantar Populer, Jakarta: Pustaka Sinar Harapan

Sulastri, dkk. 1994. "Asal- usul Nama- nama Tempat (daerah ) di Minangkabu“. (Laporan Penelitian ). Padang: Unand.

Suwondo, Bambang. 1981. Cerita Rakyat Daerah Riau. Jakarta: Proyek Penerbitan Buku Sastra dan Daerah.

Sefriyeni, Sisri. 2008. "Dokumentasi dan Klasifikasi Cerita Rakyat di Nagari Parambahan".(Skripsi SI Fakultas Sastra UNAND). Padang: Fakultas Sastra Universitas Andalas.

Zuriati dan Ivan Vadilla. 1999. “Pergeseran Makna dalam Pengindonesiaan Nama Daerah Studi Asal Usul Daerah di Sumatera Barat". (Laporan Penelitian). Padang: Unand.

Zulkarnaini. 1996. Bukittingi Budaya Alam Minangkabau: Padang :CV Mitra Ikhlas 